\title{
Cutaneous New World Leishmaniasis on a Port-wine stain birthmark ${ }^{*}$
}

\author{
Paulo Ricardo Criado ${ }^{1}$ \\ Aliene Noda ${ }^{1}$
}

\author{
Neusa Sakai Valente ${ }^{1}$ \\ Walter Belda Junior ${ }^{1}$
}

Abstract: We present an interesting case report of two sarcoid-like lesions on a port-wine stain (PWS) birthmark in a Brazilian patient which on investigation proved to be cutaneous leishmaniasis.

Keywords: Hemangioma, capillary; Leishmaniasis, cutaneous; Port-Wine Stain; Tropism

A 30-year-old housewife who was born and lived in the state of Maranhão in the northeast of Brazil was admitted to our dermatology department with a complaint of two painless erythematous infiltrative papules on her forehead that had started two months previously. Her stepdaughter had been treated for cutaneous leishmaniasis on her leg. The patient presented with two nonulcerated erythematous infiltrative papules which measured 8 and $10 \mathrm{~mm}$ in diameter on a Port-wine stain (nevus flammeus) on the left side of her forehead (Figure 1). An intradermal test for leishmaniasis (Montenegro test) was positive $(10 \mathrm{~mm})$. A cutaneous biopsy was taken and processed for conventional optical microscopy using H\&E, Fite-Faraco, PAS and Grocott-Gomori stains and for immunohistochemistry to detect Leishmania. ${ }^{1-3}$ Histopathology revealed chronic diffuse dermatitis with a granulomatous tissue reaction and plasmacytosis (Figure 2A). Immunohistochemistry staining to detect Leishmania antigens performed as previously described using antibodies against Leishmania chagasi was positive (Figure 2B). ${ }^{46}$ Histological staining and cultures for acid-fast bacilli and fungi were negative.

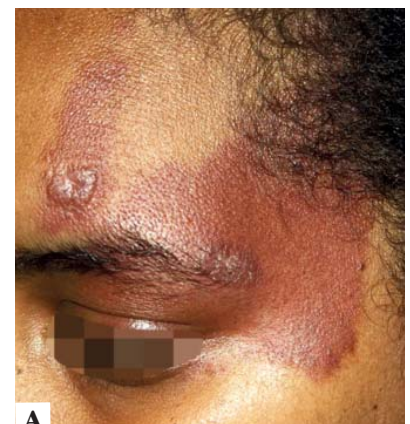

A

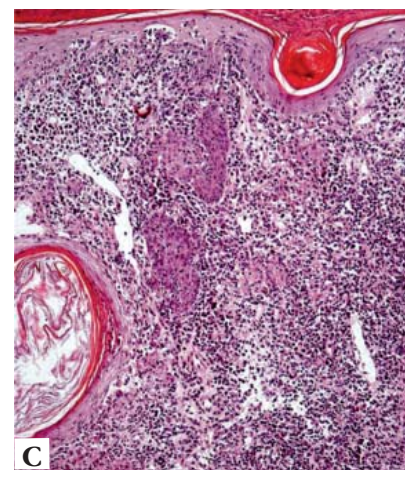

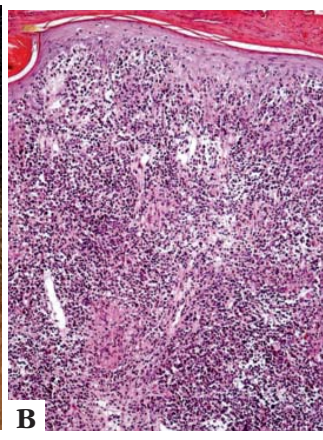

Figure 1:

A. Port-wine stain birthmark in the left frontotemporal area. Note the two sarcoid-like lesions on the hemangioma; $\mathbf{B}$ and $\mathbf{C}$. Histopathological examination of hematoxylin- eosin (H\&E)-stained tissue revealed dermal granulomatous inflammation with a predominantly lymphoid infiltrate, several plasma cells and dilated blood vessels with thin walls (H\&E; OM 200x)

\footnotetext{
Received on 12.02.2013.

Approved by the Advisory Board and accepted for publication on 18.06.2013.

Study carried out at the Mycology and Leishmaniasis Outpatient Unit, Department of Dermatology, Hospital das Clínicas, School of Medicine, University of São Paulo (HC-FMUSP), São Paulo, SP, Brazil.

Conflict of interest: None

Financial funding: None

Universidade de São Paulo (USP), São Paulo, SP, Brazil
}

(C)2014 by Anais Brasileiros de Dermatologia 

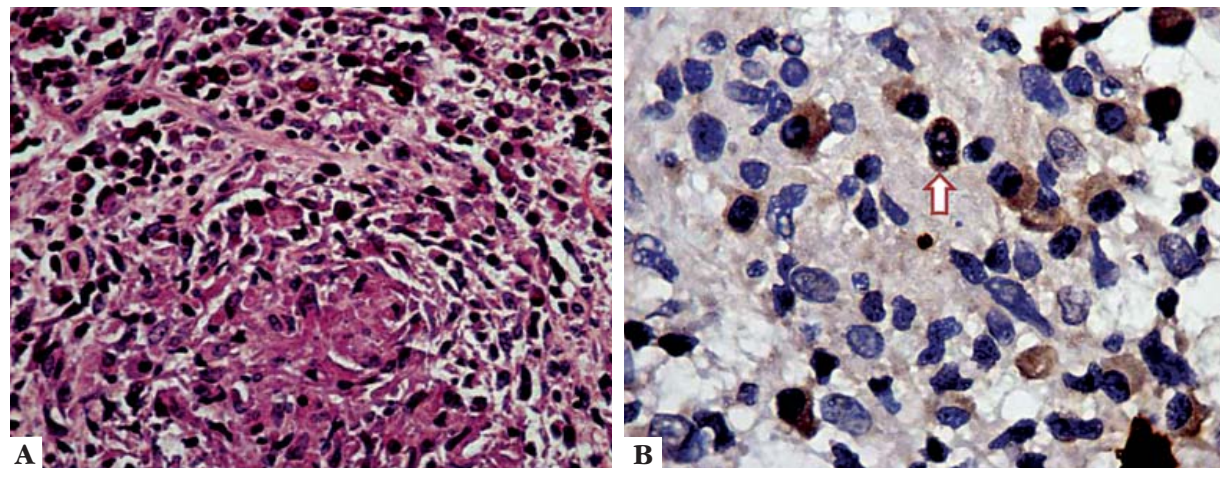

Figure 2: A. Detail of the histopathological examination showing dermal granulomatous inflammation with a with numerous lymphoid and plasma cells. (H\&E; OM 400x); B. Immunohistochemistry with anti-Leishmania antibody (ABC peroxidase) showing a few amastigote structures (arrow) inside the macrophage cytoplasm
This is the first report of cutaneous leishmaniasis on a hemangioma in the literature. We believe a sand fly was attracted to the lesion to feed probably because of the increased vascularization in this area. Mann et al. suggested that the attraction of Lutzomyia spp. to colors and odors was species-specific and demonstrated that certain colors, such as red and red-blue, exert a greater attraction on these

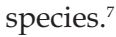

\section{REFERENCES}

1. Penna GO, Domingues CM, Siqueira Jr JB, Elkhoury AN, Cechinel MP, Grossi MA, et al, Dermatological diseases of compulsory notification in Brazil. An Bras Dermatol. 2011;86:865-77.

2. Stebut EV. Immunology of cutaneous leishmaniasis: the role of mast cells, phagocytes and dendritic cells for protective immunity. Eur J Dermatol. 2007;17:115-22.

3. Basu MK, Ray M. Macrophage and Leishmania: an unacceptable coexistence. Crit Rev Microbiol. 2005;31:145-54.

4. Amato VS, Tuon FF, de Andrade HF Jr, Bacha H, Pagliari C, Fernandes ER, et al. Immunohistochemistry and polymerase chain reaction on paraffin-embedded material improve the diagnosis of cutaneous leishmaniasis in the Amazon region. Int $\mathrm{J}$ Dermatol. 2009;48:1091-5.

5. Carrasco L, Pastor A, Fariña C, Martín L, Manzarbeitia F, Requena L. Acral arteriovenous tumor developed within a nevus flammeus in a patient with Sturge-Weber syndrome. Am J Dermatopathol. 2003;25:341-5.

6. Lefèvre T, Koella JC, Renaud F, Hurd H, Biron DG, Thomas F. New prospects for research on manipulation of insect vectors by pathogens. PLoS Pathog. 2006;2:e72.

7. Mann RS, Kaufman PE, Butler JF. Lutzomyia spp. (Diptera: Psychodidae) response to olfactory attractant- and light emitting diode-modified Mosquito Magnet X (MM-X) traps. J Med Entomol. 2009;46:1052-61.

\author{
MAILING ADDRESS: \\ Paulo Ricardo Criado \\ Av. Dr. Enéas de Carvalho Aguiar, 255 \\ Cerqueira César \\ 05403-000 - São Paulo - SP \\ Brazil \\ E-mail:prcriado@uol.com.br
}

How to cite this article: Criado PR, Valente NS, Noda A, Belda W Jr. Cutaneous New World Leishmaniasis on a Port-Wine Stain Birthmark. An Bras Dermatol. 2014;89(4):669-70. 